\title{
Mean Platelet Volume and Uric Acid Levels in Neonatal Sepsis: Correspondence I
}

\author{
Ömer Kartal • Ayșe Tuğba Kartal
}

Received: 22 April 2014 / Accepted: 9 June 2014 / Published online: 1 July 2014

(C) Dr. K C Chaudhuri Foundation 2014

To the Editor: We have read with great interest the recent article by Aydin et al. In this excellent study, the authors investigated the role of mean platelet volume (MPV) and uric acid levels in the diagnosis of neonatal sepsis (NS) [1]. They concluded that the combined use of c-reactive protein (CRP) and MPV should be considered in the early diagnosis of NS; however uric acid levels may only be utilized as an additional tool to support diagnosis. Although the study provides exhaustive data, and we acknowledge their contribution to the field, but we believe that some additional comments might be valuable.

CRP, an acute phase reactant increases in inflammatory conditions. Additionally, CRP is not a sensitive test at birth because it requires an inflammatory response to increase its level [2]. So it has a poor specificity and it is a poor predictor for neonatal sepsis, besides it elevates in other noninfectious inflammatory conditions including maternal fever, fetal distress, stressful delivery, perinatal asphyxia, meconium aspiration, and intraventricular hemorrhage $[2,3]$.

According to some studies, there is no difference in levels of MPV and uric acid in neonates with and without sepsis [4]. This may be due to the complicated and multifactorial etiology of sepsis. That is, these two parameters are still controversial issues for sepsis evaluation.

As to further studies, procalcitonin (PCT) is one of the most useful marker for diagnosis of sepsis in critically ill patients. An increased PCT level appears to be a highly specific and sensitive marker of sepsis in the first hours of life [5]. In addition, procalcitonin is more sensitive and specific than CRP and most of the other markers. However, it cannot be recommended as the single definitive test for sepsis diagnosis; it must be interpreted with careful medical history, physical examination and microbiological assessment.

Consequently, an ideal marker for sepsis does not exist currently. Sepsis is a pathophysiological process rather than a specific syndrome and is too complex to be described by a single measure and thus must be evaluated with clinical findings.

Conflict of Interest None.

Source of Funding None.

\section{References}

1. Aydın B, Dilli D, Zenciroğlu A, Karadağ N, Beken S, Okumuş N. Mean platelet volume and uric acid levels in neonatal sepsis. Indian J Pediatr. 2014. doi:10.1007/s12098-014-1417-4.

2. Escobar GJ, Puopolo KM, Wi S, Turk BJ, Kuzniewicz MW, Walsh EM, et al. Stratification of risk of early-onset sepsis in newborns $\geq 34$ weeks' gestation. Pediatrics. 2014;133:30.

3. Gyawali N, Sanjana RK. Bacteriological profile and antibiogram of neonatal septicemia. Indian J Pediatr. 2013;80:371-4.

4. Cekmez F, Tanju IA, Canpolat FE, Aydinoz S, Aydemir G, Karademir F, et al. Mean platelet volume in very preterm infants: a predictor of morbidities? Eur Rev Med Pharmacol Sci. 2013;17:134-7.

5. Wacker C, Prkno A, Brunkhorst FM, Schlattmann P. Procalcitonin as a diagnostic marker for sepsis: a systematic review and meta-analysis. Lancet Infect Dis. 2013;13:426-35.

Ö. Kartal $(\bowtie)$

Department of Pediatrics, Aksaz Military Hospital, 48750 Mugla,

Turkey

e-mail: dr.omerkartal@hotmail.com

A. T. Kartal

Department of Pediatrics, Marmaris State Hospital, Mugla, Turkey 